\title{
The Enthymeme in Aristotle's Rhetoric: From Argumentation Theory to Logic
}

\author{
Antorne C. Braet Rijksuniversiteit Leiden
}

\begin{abstract}
Which properties are characteristic of the enthymeme in Aristotle's Rhetoric? There is no consensus on this point. The present discussion centres on three properties. 1. Is there always an implicit premise? (Answer: Above all, a pragmatic level and a logical level must be distinguished.) 2. Do the premises consist by definition of probabilities and signs? (Answer; No.). 3. Are all enthymemes reducible to a syllogistic form? (Answer: The literature pertaining to this question is dominated by a false dilemma: an enthymeme does not have either a topical or a syllogistic structure). In general, Aristotle's approach to the enthymeme in the Rhetoric appears to shift

from argumentation theory to logic.
\end{abstract}

Résumé: Il n'y a aucun consensus sur ce qui caractérise les enthymèmes dans la Rhétorique d'Aristote. Dans cet article on concentre sur trois questions. I.Y a-t-il toujours une prémisse implicite? (Réponse : il faut surtout distinguer les niveaux pragmatique et logique.) 2 . Les prémisses sont-elles par définition des probabilités et des signes ? (Réponse : Non.) 3. Est-ce que les enthymèmes peuvent se réduire à une forme syllogistique? (Réponse : les écrits relatifs à ce sujet se fondent sur un faux dilemme : un enthymème n'a aucune structure syllogistique ou thématique. En général, l'apporoche d'Aristote sur les enthymèmes dans la Rhétorique semble varier entre la théorie de l'argumentation et la logique.

Keywords: enthymeme, implicit premise, probabilities and signs, topical and syllogistic structures, argumentation schemes, forms of argument

\section{Introduction}

One of the most widely discussed subjects in informal logic and argumentation theory is the concept of the enthymeme. I need only refer to the series of articles published in this journal on "The Case of the Missing Premise" (Levi 1995, with references).

All modern theorists are aware that the concept of the enthymeme goes back to Aristotle's Rhetoric. They are also convinced that the designation "abbreviated syllogism" which is ascribed to this concept in introductions to logic deviates from the original Aristotelian view. However, what few people know is that specialists (philologists, scholars of ancient philosophy, etc.) are still hotly debating the issue of the precise sense of this concept in the Rhetoric.

In effect, there is only one point on which the specialists agree: Aristotle reserved a central role for the enthymeme in his Rhetoric. But there is no consen- 
sus on how the three properties which he ascribes to the enthymeme in Chapter 2 of Book 1 should be interpreted. Scholars continue to put forward properties which they consider crucial.

What I intend to do in the present article is to evaluate the discussions which have thus far been devoted to the three properties which Aristotle ascribes to the enthymeme. I will do so from the perspective of modern argumentation theory, which in my view offers two advantages. First, it supplements the dominant logical approach presented in the two highly enlightening studies by Sprute (1982) and Burnyeat (1994; abridged and popularized version, 1996), which place rather too much emphasis on the question of the deductive validity of the relationship between premise (or premises) and conclusion. And in the second place, such an approach is better calculated to highlight the parallels with modern "enthymeme issues". We need only compare the vision of Solmsen and Ryan on the "absent premise" in the work of Aristotle, which we will be examining below, with that of Hitchcock on enthymematic arguments (1985). Although my immediate aim is simply to contribute to the historiography of an early phase in argumentation theory, I hope that indirectly I may succeed in shedding some light on modern controversies. In this respect, the major contribution is probably to be found in Section 3, which focuses on the false dichotomy assumed in Aristotelian scholarship between an argument's being topic-based and its being syllogism-based.

Before proceeding to list the properties which Aristotle attributes to the enthymeme, I will indicate broadly the place of this device in the Rhetoric.

In the polemical first chapter, Aristotle accuses the rhetoricians of his day of concentrating on emotional means of persuasion, while disregarding enthymematic argumentation. In his second chapter, he goes on to distinguish the three wellknown means of persuasion: ethos, pathos and logos. The last term refers to the correct, or apparently correct, presentation of arguments related to the central issue. According to Aristotle, this rhetorical argumentation can take one of two forms, analogous to the situation in analytics (logic) and dialectics: the "inductive" form, i.e., a paradeigma, or the "deductive" form, i.e., an enthumema or "rhetorical syllogism" (1.2.8: 1356a35-b10). The remainder of Chapter 2 consists of a description and an exposition of three properties of an enthymeme.

Chapter 3 contains the second fundamental division of the Rhetoric into three parts, based on the three types of speech: deliberative, ceremonial and judicial. Following this division, Book 1 is devoted entirely to a discussion of the protaseiswhich for now I will refer to as premises of enthymemes-per type of speech.

Curiously enough, later on (in Book 2) Aristotle again embarks on a general treatment. Chapter 22 of this second book contains a kind of recapitulation of the three properties from Chapter 2, Book 1, while Chapter 23 and subsequent chapters are devoted to correct and incorrect enthymemes on the basis of general topics, and a critique of various types of arguments. 
Book 3, which deals with the style and the disposition of speeches, refers only in passing to the stylistic and compositional use of the enthymeme.

Although there is undeniable evidence of the necessary continuity in this treatment, and one gets the impression that that Aristotle intended the explanation to function as a coherent and consistent entity, most interpreters have come to the conclusion that his discussion of the enthymeme does not in effect form a unity. Since 1929, when Solmsen launched his famous "zweifache Enthymemtheorie" (Solmsen 1929, 31), no small number of studies have focused on the question of the unity or otherwise of Aristotle's treatment. The central question is to what extent enthymemes can be reduced to the categorical syllogism from the Prior Analytics, with its three terms, figures and moods. According to Solmsen, this is to some degree possible, although the Rhetoric also contains passages-as in Book 2 , Chapter 23-in which the enthymeme is based on a topical rather than a categorical-syllogistic structure. In Solmsen's view, these passages stem from an older "layer" of the Rhetoric, dating from the period of the older Topics, while more recent layers were conceived after the development of syllogistics in the later Prior Analytics. This is also related to the infamous "ambuigity" of the term sullogismos: one minute we are expected to see it in a general sense, as any deductive method of reasoning (pre-analytical), and the next minute specifically as the categorical three-termed syllogism (post-analytical).

Preparatory to my discussion, I will present the description and the three properties of the enthymeme from Book 1, Chapter 2.

According to Aristotle, we speak of an enthymeme "if, certain things [premises] being the case, something else [the conclusion] beyond them results by virtue of their being the case, either universally or for the most part" (1.2.9: 1356b15-17).

The three properties which Aristotle then ascribes to the enthymeme are as follows:

1. Enthymemes deal with largely non-necessary matters, namely human actions, and for this reason are derived from probabilities and signs, eikota and sémeia (1.2.14: 1357a22-33; cf. 1.3.7: 1359a7-8, 2.21.2: 1394a26, 2.25.8: 1402b14).

2 Enthymemes are used for the benefit of an uneducated audience, and this makes a concise formulation more appropriate. Moreover, as familiar assumptions can be left unexpressed, an enthymeme is often derived from fewer statements than a prōtos sullogismos, a standard sullogismos (1.2.12-13: 1357a3-22, cf. 2.22.3: 1395b24-26 and 3.18.4: 1419a18-19).

3. Like dialectical sullogismoi, enthymemes are the type of sullogismoi whereby we refer to topoi (here, topoi koinoi or common and relatively formal topics), as opposed to special and material topics, such as idia or eide; although enthymemes from common topics are seen as more characteristic of rhetoric, according to Aristotle enthymemes from special topics are more frequent $(1.2 .21$ 22: 1358a10-35, cf. 2.22.16-17: 1396b28-97al and 3.1.1: 1403b14-15). 
As we have seen, the interpretation of these properties has not as yet resulted in a consensus. No doubt this is due in part to the uncertainty surrounding the text passages referred to here. For this reason, it may be useful to supplement these with examples of enthymemes, even though this presents us with a problem, in that it is not always clear whether a particular example is actually an enthymeme.

Only the following four (!) examples are explicitly designated as enthymemes by Aristotle.

a. "It is never right for who is shrewd to have his children taught to be too wise, for apart from the other idleness they have, they incur hostile jealousy from fellow citizens" (2.21.2: 1394a29-34, taken from Medea by Euripides; if the reason is omitted, this enthymeme becomes a gnōmē or maxim).

$b$. "There is no one of men who is free, for he is a slave of money or of chance" (2.21.2: 1394b4-6, taken from Hecuba by Euripides; here, too, the omission of the reason results in a gnōmê).

c. "[It would be terrible] if when in exile we fought to come home, but having come home we shall go into exile in order not to fight" $(2.23 .19$ : 1399b15-17, taken from a speech by Lysias; of the many examples in 2.23 , this is the only one that is explicitly called an enthymeme).

d. "If it is necessary to seek reconciliations whenever such changes are most profitable and most advantageous, then it is necessary to seek changes when one is successful" (3.17.17: 1418b36-38, a reference to a speech by Isocrates).

In addition to these unambiguous examples, there are many more which are generally considered enthymemes, although in the majority of cases this is more or less questionable. The least questionable of these-although the interpretation as argumentation is troublesome-is the Dorieus example in 1.2.13, which Aristotle himself clearly links to the enthymeme and which I quote below. The examples in 1.2.17-18, referred to literally as illustrations of semeia or signs, may fairly safely be interpreted or paraphrased as examples of enthymemes which are based on a sign relation. For example, "he is ill, because he has a fever"; "he has a fever, because he breathes rapidly".

The many examples in Book 2, Chapter 23 are more problematic. These are generally seen as examples of enthymemes, but Aristotle specifies this only in the case of example $c$. above. In all the other cases, the examples are presented as illustrations of common topics. Thus the fourth topic, "from more and less", is accompanied by the example: "if not even the gods know everything, hardly can human beings" (2.23.4: 1397b12-13). It is even possible to interpret this example, and most of the others in 2.23 , not as enthymemes, but rather as concrete warrants (see Section 4 below).

I will now turn to the interpretation. Here I will operate from "outside" to "inside": from the formulation, the verbal presentation of the enthymeme in the text, to the "internal" properties, both the substantial nature of the statements which make up the enthymeme and the more or less formal nature of the structure 
on which the whole enthymeme rests. This means that I will start with Aristotle's property 2 , go on to property 1 , and conclude with property 3 .

\section{The formulation of the enthymeme: the issue of the implicit premise}

With regard to the implicit premise, the various views may be summarized as follows. (1) Aristotle himself-in accordance with what would later become the standard definition-considered an enthymeme to be a syllogism with an implicit premise (this is the interpretation of Cope 1867,103, note 1, which in general is no longer taken seriously). (2) No, this standard definition is post-Aristotelian; according to Aristotle, an enthymeme may contain an unexpressed premise, but this is not necessarily so. In any case, this is an incidental rather than a defining property (the dominant view, most recently expressed by Burnyeat 1994, cf. Sprute 1982). (3) No, where Aristotle is concerned, it is totally incorrect to speak of implicit premises: the many enthymemes with only one premise in the Rhetoric should not be supplemented by the addition of a supposedly unexpressed premise (Ryan 1984).

Let us begin by looking at the four examples presented as true enthymemes.

What immediately strikes one is the fact that the examples are so heterogeneous. As regards the two differences which I will be discussing here, this would appear to be related to the source: they are derived from existing, in some cases literary (!), sources (all the examples $a$. through $d$.), as opposed to those which have apparently been invented (as in the examples of sign arguments to be found in modern textbooks of logic: "he is ill, because he has a fever").

The first difference in formulation that I would like to point out lies in the style of the enthymeme. Some examples are formulated in a factual manner, while others-in particular the examples quoted here-are styled "rhetorically". The chiastic antithesis in example $c$, for example, is noteworthy. Furthermore, if we characterize all the examples from 2.23 as enthymemes, then we are left with a great many rhetorical questions. (In Book 3, where Aristotle discusses such aspects as style, there are various references in 3.9 and 11 not only to the desirability of antithetical formulations, but also to the importance of avoiding metaphorical formulations of enthymemes which are overly transparent or strained; $c f$. Sprute 1982, 132).

In this light, one gets the impression that the effect of at least some enthymemes is not due exclusively, or even primarily, to the content and structure of the argument, but rather to the arresting formulation. With regard to this stylistic aspect, we are apparently seeing the consequences of the popular description of the enthymeme - both before and after Aristotle - as a "striking formulation" ( $c f$. Conley 1984).

A second difference to which I would like to direct the reader's attention is the wide-ranging complexity of the statements which make up the enthymemes in the 
examples. On the one hand, Aristotle puts forward enthymemes which consist of rather complex statements. These are the examples $a$. through $d$ above, which were derived from existing texts and designated as enthymemes by Aristotle himself. On the other hand, he also makes use of quite simple examples - such as "he is ill, because he has a fever"-which are presented as signs and were apparently invented in order to serve as illustrations.

This difference in complexity has major repercussions for the reducibility of the examples to logical forms of argument. The sign enthymemes, with their three terms, can easily be reduced to valid or invalid syllogisms from the Prior Analyticswhich Aristotle actually does in this last work (2.27), a process to which he refers in Rhetoric 1.2.18: $1357 \mathrm{~b} 25$ and 2.25.12: $1403 \mathrm{a} 5$ and 12 . However, this is impossible where the more complex examples are concerned, if only because they consist of too many terms (and/or terms in two different roles in a way that syllogistic cannot represent, $c f$. Burnyeat 1994, 23-24). Later on we will see that ultimately these examples can best be reduced to post-Aristotelian propositional-logical forms of argument.

The general impression that remains is that Aristotle's "enthymeme" was used in at least two, not entirely compatible, senses. Sometimes he employs the term for arguments which appear in actual texts, and which owe their effect at least in part to their stylistic form. Here it is not possible to reduce the examples to syllogistic forms of argument based on Aristotle's logic. Elsewhere we see constructed examples where this is possible, and where, as in 1.2.14-19 (cf. 2.25.8-14), there is an explicit link with the three-termed syllogism from the Prior Analytics. In the context of the constructed examples there is no mention of any striving for stylistic effect. As the first sense is in accordance with pre-Aristotelian tradition and the second with the syllogistic of Aristotle, which was developed relatively late, one gets the impression that what we see here are an older and a more recent sense.

What, then, can we say about the question of the implicit premise, in view of the ambiguity of the term 'enthymeme'? I will examine this question by beginning with what I see as the clearest case, the enthymeme which can be reduced to an analytic syllogism, as it occurs in the passage 1.2.14-19 (cf. 2.25.8-14). We need only think of examples of sign arguments such as "he is ill, because he has a fever".

Given the fact that, according to Aristotle's own reconstruction in Prior Analytics 2.27 , these enthymemes with a single premise can be reduced to syllogistic forms of argument, one may assume that Aristotle took the view that, logically speaking, in this type of enthymemes one premise is unexpressed. In fact, he himself notes that in the enthymematic variant of a syllogism, one of the premises of the syllogistical pendant is left out. The explanation which he gives (Prior Analytics 2.27: 70a19-20) is that in enthymemes such as "he is ill, because he has a fever", wellknown generalizations such as "someone who has a fever is sick" can be omitted. 
Thus it seems certain that in the case of one-premise enthymemes which can be reduced to categorical syllogisms, Aristotle assumed the existence of an implicit premise. His standpoint on other enthymemes or the enthymeme in general is more difficult to determine.

An initial point of departure might be the quoted description of the phenomenon "enthymeme": ". . . if, certain things [premises] being the case, something else [the conclusion] beyond them results by virtue of their being the case, ...". Like other descriptions of the dialectic and logical sullogismos, this description would appear to imply that Aristotle assumed that every enthymeme contains a reasoning with at least two premises. In his view, the essence of an enthymeme is that the fact that certain things are so means that something else is so. In other words "something else" (the conclusion) results from certain things (plural, thus two premises). This would seem to indicate that in any enthymeme with only one premise, which includes all the examples $a$, through $d$, at least one premise is implicit.

This is in keeping with the-likewise general-explanation for omitting premises in Rhetoric 1.2.13: 1357a16-22 (cf. the clarification in the Prior Analytics quoted above). Here Aristotle notes that an enthymeme "is derived from a few statements [premises], often fewer than the protos sullogismos", the prototype of the sullogismos (that is, a deduction with at least two premises). He gives as the reason the fact that premises which the audience are familiar with and can easily fill in need not be stated. For example, everyone knows that the winners at the Olympic Games receive a crown. Thus it is not necessary to include this information when arguing that Dorieus was the winner of a competition where the reward was a crown.

The problem with the implicit premises in "non-syllogistic" enthymemes is that Aristotle does not reconstruct them by means of an underlying logical form of argument. It would be unfair to expect him to do so, since the logical theory most suitable for that task, propositional logic, was not fully developed until well after his day. As a result, in cases such as the examples $a$. $-d$., it is at the very least unclear exactly which premises Aristotle considered implicit. I will return to this point in Section 4.

Is the presence of an implicit premise a defining property of an enthymeme? Authors whose orientation is primarily towards logic (Sprute 1982, 130-32 and Burnyeat 1994, 4-5 and 22) are inclined to stress that (a) Aristotle does not say in 1.2.13 that enthymemes always have fewer premises, but rather that they often do; and (b) even if there is such a thing as an implicit premise, this is totally irrelevant from a logical viewpoint, since logically it makes no difference whether a premise is explicit or implicit. For both these reasons, they do not consider the implicit nature of a premise to be a defining property of an enthymeme. I would suggest that a more balanced view could be put forward, with the aid of the distinction between the pragmatic and the logical level of argument. From a prag- 
matic point of view, an enthymeme-in the sense of a speech act in an oratorical situation-is always characterized by the omission of those parts of the argument which are known to the audience and which they can fill in for themselves. Whenas in theory often happens and in practice always happens-this means that only one premise is expressed, then I suggest that on the logical level at least one extra premise must be assumed. Aristotle himself probably endorsed this view, but it is only in the case of syllogistic enthymemes that the implicit premise can be reconstructed by means of Aristotelian forms of argument.

\section{The content of the enthymeme: only eikota and sēmeia?}

Some authors-notably those who take a logical approach, rejecting the notion that implicit premises are a defining property of enthymemes-maintain that the distinctive feature is more likely to be found in the content of enthymemes. They point to such places as Rhetoric 1.2.14: 1357a32-33 and Prior Analytics 2.27: $70 \mathrm{a} 10$, where we are told that an enthymeme is a sullogismos from eikota and semeia. This standpoint was recently attacked from within their own ranks by Burnyeat (1994). I believe he is right, but his reason-according to Aristotle, this type of argument is also found outside rhetoric (1994, 32 and 34, n. 84)-is less weighty than the considerations below, which come down to the fact that eikota and sēmeia are not the only kinds of rhetorical premises.

The first time that Aristotle refers to eikota and semeia in the Rhetoric (in 1.2.14), he immediately provides an explanation for the fact these are the sources [premises] from which enthymemes are derived. In his view, this is because the conclusions of enthymemes refer to matters which are seldom necessary, i.e., human actions; apparently these are the actions with which the three types of speech are concerned: policy measures, praiseworthy or objectionable acts, and acts which may be unjust. Aristotle goes on to say that in view of the fact that conclusions can only be reached on the basis of premises which belong to the same category (necessary conclusions on the basis of necessary premises, and generally non-necessary conclusions on the basis of generally non-necessary premises), the premises must have a largely non-necessary content. And according to Aristotle, this type of non-necessary premise is apparently formed by eikota and sēmeia.

Although it is easy to see that in this passage Aristotle is linking the nature of the conclusion and the nature of the premises, what he says here about the nature of rhetorical conclusions and premises is not entirely in keeping with the rest of the Rhetoric. Contrary to what is suggested here, his rhetorical premises and conclusions are not exclusively of a descriptive nature. In fact, the content is more often evaluative. The only author I know. of who has devoted attention to this point-Eggs (1984, $352 \mathrm{ff}$.)- - seems to be trying to solve the problem by declaring eikos to be not only a factual probability, but also a normative statement (353). 
However, this would appear to be impossible on the basis of Aristotle's descriptions.

Where Aristotle does adhere to tradition (see Rhetoric to Alexander $7.4 \mathrm{ff}$ : $1428 \mathrm{a} 26 \mathrm{ff}$.) is in his description of an eikos as primarily a phenomenon in the real world, or at any rate a view of the real world: "that which is known to generally occur or not occur, or generally is or is not the case" (Prior Analytics 2.27: 70a45; cf. Rhetoric 1.2.15: 1357a34-37 and 2.25.8: 1402b14-16).

It is only in the second-derived-description that we find the typical Aristotelian designation as a premise of an enthymeme: an eikos is one of the rhetorical protaseis (Rhetoric 1.3.7: 1359a8), namely a "protasis endoxos", i.e., a generally accepted premise (Prior Analytics 2.27: 70a3-4). The eikos premise is apparently seen as widely accepted because it expresses what in the view of most people generally occurs/is the case, or, conversely, does not occur/is not the case. In other words, an eikos is the type of premise that expresses a view on a regularity within the real world: it is an empirical generalization. Thus this kind of premise is of a descriptive nature, as is clear from the only two examples which Aristotles gives (Prior Analytics 2.27: 70a5-6): "jealous people are resentful" and "people who are loved are loving". It is probably no coincidence that these examples are concerned with empirical generalizations on human behaviour.

Semeion, too, is described in the Rhetoric and the Prior Analytics, on the level of the real world and as a premise of an enthymeme. In reality semeion is a situation or event (the sign that has been given) which refers to an accompanying situation or event (what is meant, what one assumes) (see Prior Analytics 2.27: 70a7-9). In view of the examples, such as fever as a symptom of illness, the relationship is not necessarily a causal one; a temporal link is sufficient (see Sprute 1982,93). This, too, is a traditional meaning (see Rhetoric to Alexander 12: $1430 \mathrm{~b} 30$ ff.). And, as in that tradition (Kennedy 1963, 99-100), Aristotle uses examples which are primarily though not exclusively concerned with physical signs. He distinguishes between signs whereby sign and signified always go together (this type of semeion has a separate name: the tekmērion), and signs whereby sign and signified often go together (there is no separate name for this type, but we will refer to it as the semeion in the stricter sense). Aristotle notes that the tekmeria occur only sporadically (Rhetoric 1.2.14: 1357a22-23 and 31-32).

As in the case of the eikos, the two subtypes of the semeion in the broader sense are referred to in Rhetoric 1.3.7: 1359a8-9 as rhetorical protaseis and in Prior Analytics 2.27: 70a6-7 as protasis apodeiktike è anankaia é endoxos, in other words, a demonstrative premise which is either (1) necessary or (2) generally accepted. In my view, this can be paraphrased as follows: (1) "If tekmêrion, then without exception the signified" (converted to a categorical premise: "all tekme $\bar{r}$ ia refer to the signified", for example "all those with a fever are ill") and (2) "if semeion in the stricter sense, then to some extent probably the signified" ("some sèmeia refer to the signified", for example "some of those who breathe rapidly are 
feverish"). The second type may be referred to as "endoxal", since-as in an eikos-people know from their own experience that sign and signified quite often go together.

On the basis of this interpretation, there is only one conclusion possible: as premises, eikota and sēmeia have a descriptive content. As such, they would also appear to be suitable for arguing the type of rhetorical conclusions which Aristle originally had in mind in the opening passage, Rhetoric 1.2.14: "matters whichunlike necessities-only occur most of the time, or are possible", 57a27-28. But we have only to look at the four examples of enthymemes, $a .-d$. above, to see that Aristotle himself did not regard either the conclusions or the premises of enthymems as limited to descriptive assertions. Of the four, only example $b$. consists of purely descriptive assertions. Many of the illustrations in 2.23 , which can possibly also be seen as examples of enthymemes, are of a normative nature. Furthermore, in the numerous places where he makes mention of rhetorical issues (the amphisbeteseis, later referred to as staseis), Aristotle demonstrates that he is well aware of the fact that it is only in exceptional cases that rhetorical conclusions refer to descriptive questions. Thus as regards the content of premises and conclusions, the Rhetoric would again appear to lack consistency.

In this connection, one of the strangest passages - and one which may have been added later (Burnyeat 1994, 35, n. 90)-is 1.3.7: 1359a6-10. Here Aristotle says, on the one hand, that the speaker must have at his disposal protaseis or premises related to the tele or "ends" (in the sense of conclusions to be reached) of the three types of speech, while on the other hand, he reminds us that the protaseis or premises of enthymemes are tekmerria, eikota and semmeia (in the stricter sense). To begin with, no conclusions can be drawn with regard to the tele, i.e., whether or not a proposal is favourable, a person's conduct praiseworthy, or an act unjust, on the basis of this type of descriptive premises. And furthermore, we see in his treatment of the protaseis from 1.4 on that Aristotle does not in fact confine himself to tekmeria, eikota and sēmeia-although this is often maintained (for example, by Solmsen 1929, 22; Grimaldi 1980, 355; and Sprute 1982, 63, though on the basis of different standpoints). A detailed discussion is beyond the scope of the present article. It will suffice to refer to the preference principles in 1.7 , such as "the scarce is preferable to the abundant" (64a24).

How then do we explain the remarkable monopoly position of the eikota and sêmeia in programmatic passages of the Rhetoric? Perhaps it is due to the dominant place of the eikota and semeia in the rhetorical tradition (Solmsen 1929, 27 and 289, Kennedy 1963,99-100). That position was itself the result of the almost exclusive attention originally reserved for the judicial speech, in which the facts were presented as probable or improbable. This may have enticed Aristotle to use eikota and sémeia as a pars pro toto for all rhetorical premises.

It is also noteworthy that the eikota and semeia are given exclusive rights in precisely those passages of the Rhetoric where the enthymeme is linked to the 
analytic syllogism. Perhaps this is because it points up the contrast with the characteristically necessary premises of the Analytics. There is also the possibility that Aristotle has given the eikota and sēmeia a preferential position because enthymemes from this type of argument appear to be the easiest to reduce to analytic syllogisms.

In any case, topical passages such as 2.23 and 24 actually give us a better idea of the variety of the content of rhetorical premises. There (2.24.5: 1401b9-14) Aristotle rightly refers to the enthymeme from a-non-necessary-sign as only one of the many possibilities. For that matter, due to the unsystematic treatment in 2.23 and 24 (see below), it is impossible to make an exact pronouncement on the scope of the content of rhetorical premises. One is inclined to say: the type of premise that can be used in the three types of speech, but the mere fact that in 2.23 and 24 Aristotle is constantly putting forward literary examples makes his position difficult to determine.

\section{The structure of enthymemes: topical vs. syllogistic}

To what extent can we attribute to the enthymeme a syllogistic structure, in the sense of the Prior Analytics? Since Solmsen (1929), this has been the sixty-fourdollar question in the literature on the enthymeme in Aristotle's Rhetoric. Even today, the answers to this question still serve to determine one's position in relation to Solmsen. Two extremes can be distinguished. On the one hand, there are those who go even further than Solmsen himself: in principle, the entire enthymeme theory in the Rhetoric is post-analytic (syllogistic in the stricter sense), with the exception of the odd pre-analytic relic such as 2.23 (which is still topical). This view is shared by Sprute (1982). Others, by contrast, deny that the Rhetoric contains a double enthymeme theory, and prefer to see the enthymeme as purely topical; this is the standpoint adopted by Ryan (1984). In between these two extremes, there are intermediate positions, such as that of Barnes (1981, 51-52, no. 55), who is supported by Burnyeat (1982, 202, no. 25 and 1994, 31 ff., notably $38, n .97)$. Barnes and Burnyeat maintain the exact opposite of Sprute's view: the pre-analytic approach is dominant, the syllogistic is marginal and was added later.

With regard to current views in modern argumentation theory, the most interesting aspect of this discussion is the fact that most disputants are trying to solve what appears to be a false dilemma. They apparently share Solmsen's assumption that an enthymeme must be based on either a topical or a syllogistic structure. However, these are actually two unlike structures: a "pragmatic" structure which is concerned with the argumentation scheme, and a "logical" structure which is concerned with the form of argument. In other words, we have here two types of structure which are not mutually exclusive, but rather merge into a single argumentation. I do not mean to say that the realization that the two are unlike and can be combined is totally lacking, but rather that no explicit and systematic distinction is made between the levels of structure. 
Of course, one might point out that Aristotle does not appear to have made this distinction with regard to the level of structure, so that working with this distinction involves an anachronism. And yet this does not have to be the case, provided one uses the distinction as an analytical instrument, without specifically ascribing it to Aristotle. What I intend to do now amounts to a re-interpretation of the passages whereby, according to fairly general insights, either topical or syllogistic enthymemes are dominant. In the initial passages argumentation schemes play a central role, but implicit forms of argument are also referred to. In the second passages, the reverse is the case.

Like Solmsen and most of the later authors, I see Book 2, Chapter 23, as the passage in which the topical approach comes to the fore most clearly. And like them, I am convinced that the majority of the enthymemes we are concerned with in this chapter cannot easily be reduced to categorical syllogisms. For that matter, this chapter deals with a highly unsystematic and heterogeneous collection of topics for enthymemes. This collection can only be discussed in an illustrative manner. I have opted for the topics number 1 and number 4 , as they are discussed fully and in a fairly explicit manner; moreover, due to their abstract contents, they provide the best impression of what Aristotle saw as a common topic.

On the basis of these two topics, I will first maintain that a topical structure, like its modern conceptualization as argumentation scheme, differs fundamentally from a logical structure. I hope to make it clear that the two types of structure are not alternatives, but rather deal with different aspects of argument. Then, from the standpoint of modern argumentation theorists, I will explain, on the basis of the first topic, how not only topical but also logical structures play a role in the topical enthymemes of 2.23 .

Aristotle introduces both topic 1 and topic 4 with a nomnclature, which in both cases displays the typical 'from' form: no. 1 is called $e k$ tōn enantiōn, from opposites (2.23.1: 1397a7) and no. 4 ek tou mallon kai hêtton, from the more and less $(2.23 .4: 1397 \mathrm{~b} 12)$. In the latter case, this is immediately followed by an example: "If not even the gods know everything, human beings can hardly do so" (1397b1213). The examples of the first topic are given below; the first is "self-control is good, for lack of self-control is harmful" (1397a10-11). The crux of both discussions is a reference to the topical principle on which the example is based. In the case of topic 1, this principle takes the form of a guideline: "One should consider whether the opposite [i.e., the opposite property] belongs to the opposite [i.e., the opposite of the subject in question], refuting the argument if it is not, confirming it if it is" (1397a8-9). In the case of topic 4, the speaker receives no guidelines; rather the rule is given which forms the basis for the example of the gods: "If a predicate does not belong to a thing to which it is more likely to belong, it clearly does not belong to a thing to which it is less likely to belong" (1397b13-15); this $a$ maiore variant is followed by two other subtypes: a minore and a pari). 
Both topic 1 and topic 4, which in fact consist of various subtypes, are concerned with principles which have certain features in common with classical forms of argument, but differ from them with regard to content and function.

Although in both cases the principles are formulated in an abstract manner, these are not formal principles. They are concerned with notions which, although general, are nevertheless substantial: "opposite" and "more or less likely (to be predicated of)". This is bound up with a twofold difference in function between topical and logical principles.

The formulation as guideline, as in topic 1 , points to the first function of a topical principle. This guideline provides an indication of how a speaker can find a relevant argumentation (in logical terms, the premise of an argument), given the standpoint (in logical terms, the conclusion of an argument) that he is defending or attacking. This is the search function of the topic. For example, if you are defending the idea that self-control is a good thing, then the topic from opposities might suggest that you could try to find out if the opposite is a bad thing. If this is indeed a view that your audience considers acceptable, then you have found a suitable argumentation.

The second function of a topical principle is expressed most clearly as rule, as in the case of topic 4 . This aspect of topics indicates that the transition between an argumentation which is found by means of a topic and the standpoint is, in principle, guaranteed. This is the guarantee function of the topic. Thus the acceptability (for the audience) of the argumentation in principle is transferred to the standpoint. Given the relevance of the argumentation which has been found, and assuming that the audience accepts the argumentation itself, then the standpoint not only follows in a logical and valid manner from the argumentation, it is in principle also substantially acceptable to the audience. If the audience accepts the relevant argumentation "lack of self-control is bad", then it will as a rule also accept the standpoint "self-control is good".

The topical principle is suitable for the twofold search and guarantee function precisely because it is a substantial principle. Formal principles cannot fulfil this double function. Modus ponens, for example, can neither suggest to a speaker a relevant argumentation nor guarantee the substantial acceptability of the conclusion. Forms of argument of this type have a different function, making it possible to subsequently test the validity of the reasoning followed in the argument.

It will be clear that in Rhetoric 2.23 , as in the Topics, Aristotle is interested in an overview of search and guarantee principles. Due in part to the fact that in this stage of his development, he does not appear to have been interested in forms of argument, scholars have not always been sufficiently aware of the fact that topical enthymemes are based on forms of argument as well as on topical principles. Since, in Aristotle, topical principles and logical principles are examined-grosso modo-one after the other, it has not always been clear that the two principles are 
present alongside one another in arguments. Another factor which plays a role here is the fact that in the "topical period", the "logical period" is also anticipated.

This brings us to the two levels of structure which in modern argumentation theory can also be discerned in the topical enthymemes in 2.23 , even though Aristotle himself appears to have been thinking only of the level of the argumentation scheme. For the sake of brevity, I will confine the analysis to the simple case of the demonstrative variant of the topic from opposites.

The "modem" argumentation scheme that corresponds to this topic can be formulated as follows:

(1) If the opposite of property $P$ belongs to the opposite of $x$, then property $P$ belongs to $x$.

(2) The opposite of property $P$ belongs to the opposite of $x$.

(3) Therefore, property $P$ belongs to $x$.

In this scheme Aristotle's topical principle is included as warrant in statement (1): the topic as warrant. This warrant is the characteristic core of the total argumentation scheme formed by all three statements together.

In arguments based on the above argumentation scheme, the reasoning is also based on a form of argument. The most obvious scheme to which these arguments can be reduced is the-post-Aristotelian-modus ponens: in the given scheme one need only abstract from the specific "opposite content" to arrive at this form. The reducibility to this form makes it clear that the reasoning in arguments according to the opposite argumentation scheme is valid.

I can be briefer with respect to the passages in which the syllogistic level of structure is dominant: the passages 1.2.14-19 and 2.25.8-15 referred to above. These short, somewhat divergent passages-which for this reason are seen by some scholars as having been added later-are devoted to enthymemes from eikota and sēmeia. The accent is on the question of the extent to which enthymemes of this type are asullogiston, "non-syllogistic", and thus luton, "refutable". The references in 1.2.18: 1357b25 and 2.25.12: 1403 a5 and 12 to Prior Analytics 2.27 make it clear that Aristotle means 'non-syllogistic' and 'refutable' in terms of the syllogistic forms of argument in the latter work or, at any rate, translatable into these terms.

Meanwhile, the topical level of structure in these passages has not disappeared, seeing that the syllogistic enthymemes discussed above are based on eikota and semeia. In effect, these are roughly the same topics concerned with the argumentation schemes which we find in the work of such authors as Schellens (1985, Ch. 5), namely, the general scheme for argumentation on the basis of regularity and the specific scheme on the basis of a sign. 
On the one hand, these passages-and to an even greater degree Prior Analytics 2.27-seem to suggest that Aristotle is trying to distance himself from the substantial topical level of structure. He is trying-in a somewhat forced manner-to reduce the various sign relations to formal figures in his syllogistics. On the other hand, it is true-as logic-oriented authors from Solmsen to Burnyeat have notedthat it is precisely in these syllogistic passages that Aristotle accepts enthymemes which in his view are not formally and syllogistically valid, but are in practice suitable, because they are based on a plausible substantial sign relation (see Sprute 1982, 108-09 and Burnyeat 1994, 38).

This completes our discussion of the passages in which, in the opinion of many authors, it is fairly clear whether the topical or syllogistical structure is dominant. The scope of this article does not allow us to explore the question of which structure dominates in those passages where this is less clear, namely in 1.4-14 and (in Book 2, in particular) 2.19. I will confine myself to the following remarks. In my view, the question at hand is whether, in his discusssion of the socalled protase is per type of speech in 1.4-14, Aristotle was actually thinking of enthymemes of any sort at all. With regard to the principles of the possible/impossible, etc., in 2.19, which are common to all types of speech, I was struck by the fact that these are in any case specific variants of the more generally formulated topical relations of opposites, comparisons (especially more and less), causality, and so forth, which we find in 2.23 .

\section{Conclusion}

All in all, it would appear that in the discussion on the enthymeme in Aristotle's Rhetoric we are seeing a shift of accent from argumentation theory to logic. Initially Aristotle's attention seems to be directed toward types of substantial relations between "premises" and "conclusions". His points of departure were arguments which he found in practice. This is the topical approach, which is elucidated by means of quoted examples. In the final-marginal-case, we see an attempt to interpret the enthymeme in terms of formal syllogistic figures. To that end, the wealth of actual arguments are laid on the Procrustean bed of categorical syllogistics: the syllogistic approach, illustrated with invented examples from the syllogistic handbook. While it is understandable that Aristotle wanted to make his brilliant discovery of syllogistics suitable for the analysis and evaluation of rhetorical argumentation, from the standpoint of argumentation theory, this was a singularly unpromising enterprise.

\section{References}

Bames, J. (1981). "Proof and the Syllogism." In E. Berti (ed.), Aristotle on Science: 'The Posterior Analytics. 'Padova: Antenore, 17-59. 
Blair, J.A. (1992). "Premissary Relevance." Argumentation 6, 203-217.

Blair, J.A. (1993). "Lieux communs et faux raisonnements." In Ch. Plantin (ed.), Lieux communs, topoi, stéréotypes, clichés. Paris: Editions Kimé, 497-505.

Brunschwig, J.(Ed.). (1967). Aristote. Topiques. Tome I: Livres I-IV. Texte établi et traduit par J. Brunschwig. Paris: Les Belles Lettres.

Burnyeat, M.F. (1982). "The Origins of Non-Deductive Inference." In J. Barnes $e t$ al. (eds.), Science and Speculation. Studies in Hellenistic Theory and Practice. Cambridge: Cambridge University Press, 193-238.

Burnyeat, M.F. (1994). "Enthymeme: Aristotle on the Logic of Persuasion." In D.J. Furley and A. Nehamas (eds.), Aristotle's Rhetoric. Philosophical Essays. Princeton: Princeton University Press, 3-55.

Burnyeat, M.F. (1996). "Enthymeme: Aristotle on the Rationality of Rhetoric." In A. Oksenberg Rorty (ed.), Essays on Aristotle's Rhetoric. Berkeley, Los Angeles, London: University of California Press, 88-115.

Conley, Th.J. (1984). "The Enthymeme in Perspective." Quarterly Journal of Speech 70, 168-187.

Cope. E.M. (1867). An Introduction to Aristotle's Rhetoric. London/Cambridge: MacMillan and Co.

Eemeren, F.H. van and R. Grootendorst (1992). Argumentation, Communication, and Fallacies. Hillsdale, N.J.: Lawrence Erlbaum.

Eggs, E. (1984). Die Rhetorik des Aristoteles. Frankfurt a. M./Bern/New York: P. Lang. Hitchcock, David, 1985, "Enthymematic Arguments." Informal Logic 7, 83-97.

Kassel, R. (ed.) (1976). Aristotelis Ars Rhetorica. Berlin/New York: De Gruyter.

Kennedy, G. (1963). The Art of Persuasion in Greece. Princeton: Princeton University Press.

Kennedy, G.A. (1991). Aristotle On Rhetoric. A Theory of Civic Discourse. Newly translated with Introduction, Notes and Appendixes. New York and Oxford: Oxford University Press.

Kienpointner, M. (1989). Semantik und Argumentation. Typologie von Mustern der Alltagsargumentation auf der Grundlage der Gebrauchstheorie der Bedeutung. Habil.schrift masch. Innsbruck.

Kienpointner, M. (1992). Alltagslogik. Struktur und Funktion von Argumentationsmustern. Stuttgart/Bad Cannstatt: Frommann-Holzboog.

Madden, E.H. (1952). "The Enthymeme: Crossroads of Logic, Rhetoric and Metaphysics." The Philosophical Review 61, 368-376.

Martin, J. (1974). Antike Rhetorik. Technik und Methode. Munchen: Beck.

Mirhady, D.C. (1994). "Aristotle, the Rhetorica ad Alexandrum and the tria genera causarum." In W.W. Fortenbaugh and D.C. Mirhady (eds.), Peripatetic Rhetoric after Aristotle. New Brunswick and London: Transaction Publishers, 54-65.

Levi, Don S. (1995). "The Case of the Missing Premise." Informal Logic 17, 67-88.

Pater, W.A. de (1965). Les Topiques d'Aristote et la dialectique platonicienne. Fribourg: Editions St. Paul. 
Pater, W.A. de (1968). "La fonction du lieu et de l'instrument dans les Topiques." In G.E.L. Owen (ed.), Aristotle on Dialectic. The Topics. Oxford: Oxford University Press, 164-188.

Pater, W. de and R. Vergauwen (1992). Logica: formeel en informeel. Leuven: Universitaire Pers; Assen/Maastricht: Van Gorkum.

Primavesi, O. (1996). Die Aristotelische Topik. Ein Interpretationsmodell und seine Erprobung am Beispile von Topik B. München: Beck.

Raphael, S. (1974). "Rhetoric, Dialectic and Syllogistic Argument: Aristotle's Position in 'Rhetoric' I-II." Phronesis 19, 153-167.

Ryan, E.E. (1984). Aristotle's Theory of Rhetorical Argumentation. Montreal: Bellarmin.

Schellens, P.J. (1985). Redelijke argumenten. Een onderzoek naar normen voor kritische lezers. Dordrecht/Cinnaminson: Foris.

Schepers, H. (1972). "Enthymem." In J. Ritter (Hrsg.), Historisches Wörterbuch der Philosophie. Darmstadt: Wissenschaftliche Buchgesellschaft, Band 2, 528-592.

Solmsen, F. (1929). Die Entwicklung der aristotelischen Logik und Rhetorik. Berlin: Weidmann.

Sprute, J. (1982). Die Enthymemtheorie der aristotelischen Rhetorik. Göttingen: Vandenhoek und Ruprecht.

Volkmann, R. (1885). Die Rhetorik der Griechen und Römer in systematischer Ubersicht. Leipzig: Teubner.

Wörner, M.H. (1981). "Enthymeme-Eine Rückgriff auf Aristoteles in systematischer Absicht." In O. Ballweg und T.M. Seibert (Hrsg.), Rhetorische Rechtstheorie. Freiburg/München: Karl Alber, 73-98.

Wörner, M.H. (1990). Das Erhische in der Rhetorik des Aristoteles. Freiburg/München: Karl Alber.

Dr. Antoine C. Braet, Dutch and Speech Communication Department University of Leiden, P.O. Box 9515, 2300 RA Leiden, The Netherlands braet@rullet.leidenuniv.nl 